ISSN 2504-1916

VoL. 18/1 (2019), 111-127

doi: 10.5450/EJM.18.1.2019.111

\title{
Music and Northern Forest Cultures
}

\author{
Tina K. Ramnarine
}

$\mathrm{F}$ orests were sacred in northern European ancient belief. Trees, in particular, were cosmologically significant, as in other contexts, including the peepal and banyan providing welfare for diverse life forms in Vedic tradition, or the tree, in Biblical tradition, as a source of knowledge. Traditional Finno-Ugric (e.g., Finnish, Karelian, and Sámi) views are that the tree supports the world because of its life-giving properties, provides a means of communicating across the worlds of the living and the dead, and represents the cosmos: the Milky Way. ${ }^{1}$ These views are linked with musical practices which, taken as a whole, can be located within a cultural domain this article identifies as northern forest cultures. By considering examples ranging from the works of Jean Sibelius (1865-1957) to contemporary folk and popular music, this article contributes to an understanding of the importance of the forest in Finno-Ugric musical practices, particularly in relation to contemporary global challenges, including climate change and environmental pressures.

In one example, traditional singers in Archangel Karelia addressed the forest as a personified agent through song, incantation, and epic narration using poetic language and a trochaic tetrameter (known as the Kalevala meter) to sing songs about the forest's birth and the methods for exploiting its resources. Singers conveyed complex relationships between humans and trees through forest imagery representing human cultural experiences within a subsistence landscape and describing hunting and human kinship, which were connected in metaphoric terms. Singers used hunting metaphors to express the unification of kin groups in traditional wedding songs. In turn, human marriage served as a model in the imagery of ritual hunting songs. To ensure a successful hunt, the hunter would sing for the forest maidens - the daughters of the forest's ruler Tapio. This was a gendered mode of musical communication that enhanced the hunter's masculinity. The forest, seen as a reciprocating agent, would sing and dance

${ }^{1}$ Clive Tolley, Shamanism in Norse Myth and Magic, Vol. 1 (Helsinki: Academia Scientiarum Fennica, 2009), 305-311. 
too. ${ }^{2}$ Such is the importance of human-forest relationships that, as the folklorist Lotte Tarkka notes, the most "tender sensuality in Kalevala meter poetry is directed at the forest, not at another human being."

The forest continues to be a metaphysical space. Musicians seek creative insight and spiritual renewal therein, contemplating musical ideas in communion with trees. In the early 1990s, the revival musician Seppo Paakkunainen introduced a tree to me as his good friend. ${ }^{4}$ We were in the forest that the composer and Sibelius biographer Bengt de Törne had described as sheltering Sibelius's home, Ainola, now a museum, with "transparent pale birches and sombre firs." Since childhood, Sibelius himself had gone into the forests "because he always felt in such good form among the silent trees." Paakkunainen's personification of the tree brought the metaphysics of the forest most strongly to my attention. His personification of the tree resonated with the conclusions of Emil, an Inuit man from Nunavut in Canada, who encountered a forest for the first time as he accompanied the ecologist Nalini Nadkarni on an expedition to a reserve in southwestern Washington in 2003. He had no word for "tree" in his Inuktitut vocabulary. A tree was "a pole." At the end of the expedition he told Nadkarni that he had learnt that trees should be treated like the elders in his village, "with great care and respect" because they "teach you things."

In this article I argue that it is critical to recognize the importance of northern forests in FinnoUgric musical contexts, and I focus on the question of cultural survival, which is bound up with concerns about ecological sustainability. Kalevala-type songs, which were compiled as the Finnish national epic, have continued to shape musical creativity up to the present day, testifying to cultural survival and addressing broader ecological themes, especially through musical depictions of the heroic, shamanic figure Väinämöinen, who sang the landscape of forests and lakes into being. The following discussion highlights cultural survival in the world views of small population groups (namely Finnish and Karelian) by outlining, firstly, the significance of the forest in the Finnish context and, secondly, the politics of language transmission with reference to the incorporation of folk song texts in the Finnish national epic, the Kalevala. Thirdly, it looks at Sibelius's nature-based aesthetic, especially in Tapiola (1926). Fourthly, it considers the evocation of the forest in contemporary folk and popular music. Overall, the main aims of

\footnotetext{
${ }^{2}$ Lotte Tarkka, "Sense of the Forest: Nature and Gender in Karelian Oral Poetry," in Gender and Folklore: Perspectives on Finnish and Karelian Culture, eds. Satu Apo, Aili Nenola, and Laura Stark-Arola (Helsinki: Finnish Literature Society, 1998), 92-142.

${ }^{3}$ Tarkka, "Sense of the Forest," 107.

${ }^{4}$ Tina K. Ramnarine, Ilmatar's Inspirations: Nationalism, Globalization, and the Changing Soundscapes of Finnish Folk Music (Chicago and London: University of Chicago Press, 2003), 42-43.

${ }^{5}$ Bengt de Törne, Sibelius: A Close-Up (London: Faber and Faber Ltd, 1937), 41.

${ }^{6}$ Santeri Levas, Sibelius: A Personal Portrait (London: J. M Dent \& Sons Ltd, 1972), xxi.

7 Cited in Nalini M. Nadkarni, Between Earth and Sky: Our Intimate Connections to Trees (Berkeley, Los Angeles: University of California Press, 2008), 3.
} 
this article are to consider the resilience of northern forest cultures in the nexus of music, language, and ecology, and to emphasize that resilience cannot be taken for granted under environmental pressures.

\section{Forests, Heritage, Sustainability}

Forests are diverse ecosystems. They play a role in climate change prevention, hydrological cycles, soil conservation, and biological diversity conservation. They are critical in meeting human subsistence needs and, in Finland, they are part of heritage and economic discourses, and they are managed though forestry law. ${ }^{8}$ The Finnish Forest Research Institute (an institution established in 1917 and operating under the Ministry of Agriculture and Forestry) notes that forests are profoundly significant in the cultural and economic lifestyles of Finns, with spiritual functions that are "heavily featured in the preservation of forest traditions, silvicultural operations, timber construction, art, music, communications and landscape protection." Scholars have conceptualized landscapes in terms of the nation state since the nineteenth century by promoting language and culture, as well as by making links between different forms of agriculture and masculine ideals that further solidified concepts of Finnish nationalism during the era of nation-building. Historians focused on the peasantry, seeing the male peasant as both embodying the national landscape and constructing citizenship and social development: he bore civic duties (because he was able to produce a community), generated national wealth, and came to define manhood in terms of individualism, freedom, and responsibility. ${ }^{10}$

Finland has the third largest forest area in Europe (after Russia and Sweden), and it has the highest forest land cover area in Europe (73 per cent). While Finland has 0.5 per cent of the global forest area, its forest industry is large with a share of up to 25 per cent in exports globally (for writing paper), as the Finnish forest researchers Matti Palo and Erkki Lehto note in a 2012 volume that adopts comparative perspectives on forest industries. ${ }^{11}$ They attribute the positive co-evolution of forestry and society in Finland to the predominant model of private, rather than state, ownership (up to 69 per cent of the total forest area). This model of private ownership combined with forestry law enforcement is relevant for the potential reduction of forest exploitation globally. Current problems of deforestation and forest degradation in tropical contexts, for example, have given way in the Finnish context to sustained-yield

\footnotetext{
${ }^{8}$ Sofia R. Hirakuri, Can Law Save the Forest? Lessons from Finland and Brazil (Jakarta: Center for International Forestry Research, 2003).

${ }^{9}$ See http://www.metla.fi/metinfo/sustainability/c6-cultural-and-spiritual.htm (accessed 1 November, 2019) and the "State of Finland's Forests" 2012 Report of the Finnish Forest Research Institute, http://www.metla.fi/metinfo/sustainability/summary.htm (accessed 1 November, 2019).

10 Ann-Catrin Östman, "The Peasants of the Forest: Masculinity, Nation, and Landscapes in Agrarian Historiography in Finland, 1900-1930," Agricultural History 82, no. 1 (2008): 62-77.

${ }^{11}$ Matti Palo and Erkki Lehto, Private or Socialistic Forestry? Forest Transition in Finland vs. Deforestation in the Tropics (Dordrecht, Heidelberg, London, New York: Springer, 2012), 4-6.
}

$$
\text { - EJM, vol. 18/1 (2019) - ISSN 2504-1916- }
$$


forestry due to policy making and market issues. ${ }^{12}$ While timber has been one of the cornerstones of the economy, the problem of its unsustainable exploitation has been greatly reduced on at least three levels. First, forestry is governed by three major legal acts to prohibit forest destruction, the first dating from 1886. ${ }^{13}$ Secondly, old growth forests, especially in southern Finland have been protected as nature reserves under the Nature Conservation Act, which was prepared in conjunction with the Forest Act (first enacted in 1886). ${ }^{14}$ Thirdly, sites in forest areas such as the Old Church at Petäjävesi (an example of timber construction in central Finland) have been included in the UNESCO World Heritage list. The state plays an important role in ecological sustainability through legal processes and international conventions.

\section{Language, Kalevala, and Finnish Nationalism}

Cultural survival was a significant concern in nineteenth-century Finnish nationalism, and political and cultural activists discussed it in terms of language maintenance; a discourse providing a model for subsequent Finno-Ugric language movements (e.g., Karelian and Sámi). The Finno-Ugric language family includes Finnish, Estonian, Karelian, Livvi, Livonian, and the Sámi languages, as well as others spoken around the Gulf of Finland and in Russia. Finno-Ugric and Samoyed languages constitute the Uralic language family. Some Uralic languages have few remaining speakers and are considered endangered. ${ }^{15}$ They are distinct from neighboring Scandinavian and Russian languages. Finland has around 5.4 million inhabitants and it is home to some of the smallest Finno-Ugric language groups such as Inari Sámi and Skolt Sámi, each with around 300 speakers (as discussed elsewhere). ${ }^{16}$ Since this article's focus is on Finnish and Karelian examples, it is worth noting that Finland and Karelia are not discrete conceptual formulations for they are connected in both geo-political and ecological landscapes, as well as through shared Finno-Ugric cultural, if not always political, histories. Karelia is a region within Finland, as well as a larger territory that has been contested, ceded to, and shared with Russia.

Nineteenth-century Finland saw the nationalist promotion of the Finnish language in governmental and literary contexts. While Swedish was the language of administration (a legacy of six hundred years of Swedish rule), the political philosopher, Johan Vilhem Snellman (1806-1881) urged readers of the Swedish language newspaper, Saima, during the early 1840s, to promote the Finnish

\footnotetext{
12 Palo and Lehto, Private or Socialistic Forestry? 4-6.

13 Hirakuri, Can Law Save the Forest? 59.

14http://www.metsa.fi/sivustot/metsa/en/NaturalHeritage/ProtectedAreas/OldgrowthForestReserves/Sivut/ MoreOldgrowthForestReservestobeEstablished.aspx (accessed 1 November, 2019).

${ }_{15}$ Fred Karlsson, Finnish Grammar, transl. Andrew Chesterman (Porvoo, Helsinki, Juva: Werner Söderström Osakeyhtiö, 1987).

${ }^{16}$ See, for example, Tina K. Ramnarine, "Musical Creativity and the Politics of Utterance: Cultural Ownership and Sustainability in Amoc's Inari Sámi Raps," in L'Image du Sápmi III, ed. Kajsa Andersson (Göteburg: Humanistic studies at Örebro University, 2013), 88-112.
}$$
\text { - EJM, vol. 18/1 (2019) - ISSN 2504-1916- }
$$ 
language spoken by the majority of the population. In the 1840s, too, textbooks on the Finnish language were published and short stories and ballads were circulated to a general readership. These texts reflected choices made in the standardization of different dialects. ${ }^{17}$ While the earliest texts in Finnish date from the sixteenth century, writers such as Aleksis Kivi (1834-1872) produced important nineteenth-century literature in the Finnish language. With texts like The Heath Cobblers (1864) and The Seven Brothers (1870), Kivi achieved the status of national writer. He was inspired by the most prominent Finnish language text, which was Elias Lönnrot's (1802-1884) compilation of folk-song texts, the Kalevala. ${ }^{18}$ Whereas literary Finnish had been based on the south-western dialects, the Kalevala included Karelian elements, thus enriching the language of literature with the nation's eastern dialects. ${ }^{19}$ It prompted scholars to collect folk poems and folk songs for further study, and it inspired artists and composers. Heroes from the Kalevala, such as Kullervo, were depicted in Finnish novels, art works, and musical compositions. In 1860, the Finnish Literature Society organized a play writing competition, which Kivi won with a play in five acts, Kullervo. In the same year, Filip von Schantz's Kullervo Overture was premiered. The composer, conductor, and champion of Sibelius's music, Robert Kajanus (1856-1933), composed an orchestral work, Kullervo (1881), as did Sibelius (1892). Kajanus had met Lönnrot as a young man and recounted, "The old man took out his kantele and showed me how he had written down the folk tunes he had collected. Because he did not know how to write music, he had invented his own numerical system ... For a long time I dreamed of the unattainable-that I would inherit Lönnrot's old kantele."20

The turn to Finnish as a language of literature and government offered one route to sustaining the musical traditions of northern forest cultures. The epic hero, singer, and maker of the kantele, Väinämoinen expresses this link between music, forest, and survival in the last lines of the second runo (poem, song text) in the Kalevala, in an utterance that the birch tree would be a perch for the cuckoo. He enjoined, "From thy sand-hued throat cry sweetly, With thy silver voice call loudly . . To rejoice my plains surrounding; That my woods may grow more cheerful. That my coast may grow more wealthy, And my region grow more fruitful!"21

In the late nineteenth century, the folklorist Julius Krohn (1835-1888) developed the localhistorical research method, which focused on the origins and variants of folk song texts. His motivation

${ }^{17}$ Henni Ilomäki, "Oral and Written Tradition during the Creation of the National Culture Early Fieldwork on the Kalevala Runes," Nordic Journal of African Studies 1, no. 2 (1992): 96.

18 Elias Lönnrot, Kalevala, 25th ed. (Mikkeli: Länsi-Savo, 1984 [1835]).

${ }^{19}$ Urpo Vento, "The role of the Kalevala in Finnish culture and politics," Nordic Journal of African Studies 1 no. 2 (1992): 85.

${ }^{20}$ Cited in Glenda Dawn Goss, “A Backdrop for Young Sibelius: The Intellectual Genesis of the 'Kullervo' Symphony," 19th-Century Music 27, no. 1 (2003): 55.

${ }^{21}$ Lönnrot, Kalevala, 21. 
was to discover the historical aspects of the Kalevala. ${ }^{22}$ His sons Kaarle Krohn (1863-1933) and Ilmari Krohn (1867-1960) further developed his research approach, which became known as the geographichistorical or "Finnish" method. ${ }^{23}$ By the early twentieth century, Finnish music researchers were motivated to search for common roots amongst neighboring Finno-Ugric people. Thus, Armas Launis (1884-1959) studied music of the Sámi in the north and of Ingrians in the south-east, and Armas Otto Väisänen (1890-1969) studied music in Estonia and amongst Finno-Ugric groups in Russia. ${ }^{24}$ The Kalevala's success in creative, political, and academic life is testament to a story of cultural survival into which the forest's significance is inscribed.

Due to his emergence as one of the most well-known and influential composers of the late nineteenth and twentieth centuries, Sibelius's interest in the Kalevala was important in promoting the Finnish language. His interest extended throughout his compositional career. In the last entry to his personal diary, in 1944, he wrote, "What enormous musical possibilities the Kalevala offers." 25 While Sibelius was born into a Finnish Swedish-speaking family, he attended a Finnish language school. His marriage to Aino Järnefelt (1871-1969) in 1892 further encouraged his interests in the Finnish language. In his first major work, the Kullervo Symphony (1892), Sibelius set over 200 lines from the Kalevala, and followed the principles of setting stressed and unstressed syllables, characteristic of the Finnish language, in lines such as "Kullervo Kalervon poika" ("Kullervo, the son of Kalervo"). In his last major work, Tapiola, Sibelius highlighted the cultural importance of the forest.

\section{Sibelius's Tapiola within Northern Forest Cultures}

Tapiola is one of the most well-known examples of forest imagery in musical works, especially because Tapiola is the dwelling place of the forest god Tapio (who appears in the Kalevala). Sibelius attached these explanatory lines to the beginning of the score:

\footnotetext{
Widespread they stand, the Northland's dusky forests,

Ancient, mysterious, brooding savage dreams;

Within them dwells the forest's mighty god'
}

\footnotetext{
22 Jälkimmä̈nen sarja, vihko 1 ("The Variants of the Kalevala. The Finnish national epic's materials organized according to the locations of songs: Finnish, Aunus, Ingrian and Estonian poems"). (Helsinki: The Finnish Literature Society, 1888).

${ }^{23}$ See Erkki Pekkilä, "History, Geography, and Diffusion: Ilmari Krohn's Early Influence on the Study of European Folk Music," Ethnomusicology 50, no. 2 (Spring/Summer 2006): 353-359. Also, see Ramnarine, Ilmatar's Inspirations, chapters 1 and 2 for further details of this history.

${ }^{24}$ Erkki Pekkilä, "Nationalism, Regionalism, Leftism, and Individualism," Ethnomusicology 38, no. 3 (Autumn 1994): 406.

${ }^{25}$ Cited in Erik Tawaststjerna: Sibelius Volume III: 1914-1957. Ed. and transl. Robert Layton (London: Faber \& Faber Ltd., 1988), 328.
} 
And wood sprites in the gloom weave magic secrets. ${ }^{26}$

The New York based conductor Walter Johannes Damrosch (1862-1950) commissioned this work, asking for a symphonic poem on a subject of Sibelius's own choice. ${ }^{27}$ In his interpretation of Sibelius's lines, quoted above, Damrosch drew attention to northern forest cultures. He referenced the complex cultural geographies of Karelian folk traditions, the shamanic traces in Sámi ritual, and the Kalevala by prefacing Tapiola's first performance at a New York Symphony Society concert on 26 December, 1926, with the description: "we see and feel the infinite, dark green forests; we hear the howling winds, whose icy sounds seem to come from the North Pole itself. Through all this we glimpse the ghostly shadows of gods and the strange beings that belong to Nordic mythology, whispering their secrets and making their mystical dances among the branches and trees." 28

Alongside artistic exploration of the forest during this period was a developing forest industry. Artistic and industrial worlds overlapped. In 1925, shortly before he began working on Tapiola, Sibelius conducted a benefit concert (raising funds for a children's hospital) for General Carl Gustaf Emil Mannerheim's (1861-1957) children's charity. The program included Morceau Romantique on a theme by the wood and paper industrialist Johan Jacob von Julin (1787-1853). ${ }^{29}$ The musicologist Glenda Dawn Goss points out that in the year that Sibelius was born, Frederik Idestam (1838-1916), a Finnish engineer, established a pulpwood plant within fifty miles of the composer's birthplace. Thus, Goss notes that "at the very time the Sibelius children were being raised on the idyllic, agrarian vision of Finland . . . industrialization was spreading across the country" and its forest industry (which had begun in the seventeenth century) developed due to markets for wood in Britain and the Netherlands, as well as for pulp and paper in Russia. ${ }^{30}$ This contextual approach aptly begins to situate the composer's work within the broader frames of forest cultures and industries.

An important theme for artists has been the survival of pre-industrial peasantry in Finnish forests during harsh winters and crop failure. Forest survival knowledge also fascinated international viewers of the Finnish Pavilion, designed by the architect Alvar Aalto (1898-1976) for the World Fair of 1939 in New York. ${ }^{31}$ While the forest environment could be harsh, as depicted in Aulis Sallinen's (b. 1935) opera

\footnotetext{
${ }^{26}$ Goss notes that Sibelius's effects include two versions of this poem. One emphasizes the "deep and dreamy" rather than "brooding" forests, and their "enchanting wood-nymphs" rather than "mischievous sprites." Cf. Goss, Sibelius: A Composer's Life, 425.

27 Sibelius did not make any substantial revisions to the work once he had sent it to Breitkopf \& Härtel, the publishers, but was anxious about having given up the possibility of revising it. Cf. Tawaststjerna, Sibelius Volume III, 271.

${ }^{28}$ Damrosch cited in Tawaststjerna, Sibelius Volume III, 275.

29 Tawaststjerna, Sibelius Volume III, 258.

30 Goss, Sibelius: A Composer's Life, 50.

31 Menin, "Waving from the Periphery."
} 
Punainen Viiva ("The Red Line," 1978), ${ }^{32}$ it was also a "refuge," which remained a life-long creative stimulant for both Sibelius and Aalto. ${ }^{33}$ Sibelius retreated from the social distractions of Helsinki by moving to his home, Ainola, in the Finnish forest in 1904, where he claimed that he found creative inspiration. Sibelius's interests in forest culture extended to the practices of folk singers: to their creative flexibility and continual adjustments of runic fragments that allowed "a whole to grow from parts" and that exemplified musical processes in Tapiola too. ${ }^{34}$ The architectural scholar Sarah Menin thus sees both Sibelius's Tapiola and Aalto's pavilion as “spatial drama[s] of universal relevance and appeal” for people who do not have direct experience of northern climates. ${ }^{35}$

The metaphor of space in Menin's architecturally informed analysis reappears in a reading of Sibelius's late works through the frames of the anthropology of perception. Tapiola shapes our perception of sound and space, according to the musicologist Daniel M. Grimley, because it traces an arc that "curves initially upward (and outward) from an opening feeling of concealment or veiling toward moments of rupture, luminescence, or actualization." ${ }^{36}$ This reading takes us away from analysis of a composer's late style toward thinking about perception and experience, in which Sibelius's creative self-criticism and his fascination with landscape are considered in terms of anthropology's phenomenological trends. ${ }^{37}$

We also shift away from analysis of the composer's late style toward ecological readings of the social relevance of a musical work when considering that Sibelius became one of the most renowned narrators of the ideology — underpinned by pantheistic world views and Hegelian social philosophiesthat cultural strength should be the basis for Finnish nationalism. Tapiola can be read in relation to cultural survival, the political importance of the Kalevala, and ecological debates. In view of the composer's own testimonies, scholarship on Sibelius has been attentive to the importance of the natural world on his musical thinking. Early biographers focused on Sibelius's interest in nature and on notions of organic growth in his structural thought. Bengt de Törne wrote about Sibelius's orchestration techniques,

32 See Tina K. Ramnarine, "Compositional Processes and the Aesthetics of Originality: Reflections on a Ballad in a Twentieth Century Finnish Opera," in Folk Song: Tradition, Revival and Re-Creation, eds. David Atkinson and Ian Russell (Aberdeen: Elphinstone Institute, 2004), 67-78.

33 Menin, "Waving from the Periphery," 239.

34 Menin, "Waving from the Periphery," 240.

35 Menin, "Waving from the Periphery," 251.

36 Daniel M. Grimley, "Storms, symphonies, silence: Sibelius's Tempest music and the invention of late style," in Jean Sibelius and his World, ed. Daniel M. Grimley (Princeton, Oxford: Princeton University Press, 2011), 186-226, here 219.

37 Interestingly, albeit tangentially, in order to develop this interpretation, Grimley frames Tapiola as "Immanent Critique" in dialogue with the critical theorist, Theodor Wiesengrund Adorno's synthesis of Georg Wilhelm Friedrich Hegel's (1770-1831) dialectical approach and Karl Marx's (1818-1883) arguments on economic progression. Indeed, Hegel's ideas about a critique that cannot be justified from the perspective of the form of knowledge that is being criticized, such that forms of knowledge should be investigated on the basis of their own presuppositions ${ }^{37}$ can be seen as implicitly informing Grimley's subsequent turn to an ethnographically derived conceptualization presented by the anthropologist Tim Ingold, who worked in a Finno-Ugric context and developed phenomenological perspectives based on field testimonies.

$$
\text { - EJM, vol. 18/1 (2019) - ISSN 2504-1916- }
$$


especially creating a pedal to "fuse all the different and sometimes incompatible groups of sounds" and to obtain an effect of "continuation of sonority when passing from one group of colours to another." 38 This technique is striking in the beginning of Tapiola. ${ }^{39}$ Recent studies of compositional sketches have enriched these understandings of growth, structure, and sonority by focusing on Sibelius's assembly of a variety of ideas, formulated over years, in which the creative process was one of determining which ideas belonged together, and in which order. ${ }^{40}$

It is increasingly possible to re-conceptualize the ecological dimensions of Sibelius's compositions now that music scholars are abandoning discourses about his national versus universal relevance. Moreover, moving away from an idealized image of the composer in an exotic northern landscape encourages thinking about Sibelius's work as “a nascent form of acoustic ecology" instead. ${ }^{41}$ From this perspective, Tapiola can be interpreted as a work that speaks to climate change, as a kind of "acoustic testimony for our current environmental concerns, ${ }^{\prime 42}$ thereby complementing analyses of other Finnish music examples, ${ }^{43}$ as well as developing musicology's ecological turn, which challenges assumptions about "the work" to look afresh at musical meaning. ${ }^{44}$

A reception history marked by questions about nature in Sibelius's musical imagination has prompted recent ecological readings of works such as Tapiola. In this respect, Adorno's short essay "Glosse über Sibelius," 45 first published in 1938, has received significant musicological attention. Adorno wrote about Sibelius's works as "the configuration of the banal and absurd," and he claimed that the composer's relationship with nature would be "only inwardly." Finnish forest as a way in which the composer hid himself from the critical gaze of his Austro-German teachers, ${ }^{47}$ and thus he failed to recognize the importance of the natural environment from childhood onwards in Sibelius's musical thought. The scholar of Russian literature and music Philip Ross Bullock

\footnotetext{
38 de Törne, Sibelius: $A$ Close-Up, 31.

39 de Törne, Sibelius: A Close-Up, 34.

40 Timo Virtanen, “From Heaven's Floor to the Composer's Desk: Sibelius's Musical Manuscripts and Compositional Process," in Jean Sibelius and his World, ed. Daniel M. Grimley (Princeton, Oxford: Princeton University Press, 2011), 58-73.

${ }^{41}$ Daniel M. Grimley, Jean Sibelius and his World, xi.

42 Daniel, M. Grimley, "Music, Landscape, Attunement: Listening to Sibelius's Tapiola," Journal of the American Musicological Society 64, no. 2 (2011): 394-398.

${ }^{43}$ For example, Tina K. Ramnarine, "Acoustemology, Indigeneity and Joik in Valkeapää's Symphonic Activism: Views from Europe's Arctic Fringes for Environmental Ethnomusicology,” Ethnomusicology 53, no. 2 (Spring/ Summer 2009), 187-217.

44 Marc Perlman, "Ecology and Ethno/musicology: The Metaphorical, the Representational, and the Literal," Ecomusicology Newsletter 1, no. 2 (2012), 15-21. https://www.ethnomusicologyreview.ucla.edu/content/ecologyand-ethnomusicology-metaphorical-representational-and-literal (accessed 1 November, 2019).

45 Theodor W. Adorno, "Gloss on Sibelius," transl. Susan H. Gillespie in Jean Sibelius and his World, ed. Daniel M. Grimley (Princeton and Oxford: Princeton University Press, 2011), 333-337.

46 Adorno, "Gloss on Sibelius," 335.

47 Adorno, "Gloss on Sibelius."
} 
suggested that Adorno was "affronted by the lack of British interest in Mahler's music," and that his essay resulted from his experience of British musical life rather than from "German avant-garde hostility to Sibelius as a figure of reactionary nationalism." ${ }^{48}$ The musicologist Max Paddison further explores Adorno's critique and outlines three ways of considering questions about the relationship between music and nature. Firstly, music is seen as a representation of nature, secondly, as embodying nature thereby prompting ontological questions about music, and thirdly, as dealing with meanings and feelings ascribed to nature. In relation to the first of these, he suggests that Sibelius's Tapiola could be seen as combining "the impression of storm and wind in trees through the use of rapid, interlaced pianissimo muted string figurations." ${ }^{49}$ Instead of viewing music and nature in terms of representation, ontology, or meaning, Paddison adopts a perspective on nature as a historical and social construct to examine Adorno's criticism of Sibelius (including comments on the composer's "trivial" use of materials through which nature is represented). Paddison concluded that Adorno's critique emerged from a "relapse into the myth of nature that accompanied the rise of authoritarianism in the first half of the twentieth century." ${ }^{50}$ Thus, by reading Sibelius through Adorno's evaluations of the composer, Paddison foregrounds contexts such as the rise of Nazi Germany, Fascism in Europe, Kant's ideas about the sublime and the individual's rational faculties, which transcend "elemental forces of nature," as well as the importance of the folk expressed in Herderian terms that relate to the rise of German nationalism. ${ }^{51}$

Other important facets of the Sibelius's compositional outlooks were his international travels, the popularity of his music in Great Britain and the United States, and Russian influences on his musical thinking. ${ }^{52}$ Nevertheless, my argument is that the context of northern forest cultures is especially informative since deeply held values and beliefs about forests persisted in nature-based cosmologies (which became interwoven with modern Finnish Lutheranism) and in Finnish nationalism during the nineteenth and twentieth centuries. ${ }^{53}$ This context has not been duly considered because of a musicological emphasis on locating Sibelius within modernism (taking into account the composer's own wish to eschew the label "nationalist"), but it is the more enduring cultural one. ${ }^{54}$ In what follows, we see

\footnotetext{
48 Bullock, The Correspondence of Jean Sibelius, 33.

${ }^{49}$ Max Paddison, "Art and the Ideology of Nature: Sibelius, Hamsun, Adorno," in Jean Sibelius and his World, ed. Daniel M. Grimley (Princeton, Oxford: Princeton University Press, 2011), 173-185, here 174.

50 Paddison, "Art and the Ideology of Nature," 183.

51 Paddison, "Art and the Ideology of Nature."

52 Philip R. Bullock, "Sibelius and the Russian Traditions," in Jean Sibelius and his World, ed. Daniel M. Grimley (Princeton, Oxford: Princeton University Press, 2011), 3-57.

${ }^{53}$ See Tina K. Ramnarine, "Sonic Images of the Sacred in Sámi Cinema: from Finno-Ugric Rituals to Fanon in an Interpretation of Ofelaš (Pathfinder)," Interventions: Journal of Postcolonial Studies 15, no. 2 (2013): 239-254.

${ }^{54} \mathrm{I}$ also pursue this kind of ecological reading of Sibelius's violin concerto, see Tina K. Ramnarine, Jean Sibelius's Violin Concerto (New York \& Oxford: Oxford University Press, 2020).
} 
that Sibelius's interests in language and nature are paralleled in contemporary musical examples, which speak, likewise, to the cultural survival of northern forest cultures.

\section{Kalevala Traditions in Contemporary Folk and Popular Music}

Following the publication of the Kalevala, the continuation of scholarly collections of folksong texts resulted in 33 volumes of The Ancient Poems of the Finnish People (published between 1908 and 1948). These volumes contain 85,000 texts in Kalevala meter. ${ }^{55}$ Materials collected from the nineteenth century onwards have been deposited in the archives of the Finnish Literature Society, providing sources for twentiethand twenty-first centuries' music revival movements and characterizing the institutionalization processes that have underpinned cultural survival, sustainability, and resilience in the Finnish context. In the 1990s, the Kalevala provided a lyrical linguistic model in popular music for various reasons: "for the skinheads because of their xenophobia, for heavy rock enthusiasts because of their interest in Finnish mythology and ancient times, and for the [musicians of the] hip-hop movement because of their use of the Finnish language and its dialects. ${ }^{56} \mathrm{New}$ genres emerging from the indie and contemporary folk music scenes, such as "forest folk," continue to draw attention to human-forest relationships. Forest folk musicians use sampled sounds or imitate bird sounds by whistling as part of a nature-inspired sonic palette, and attract media attention as creating "a highly inventive and unique musical world." 57 Web music videos depict musicians walking through the winter forest. ${ }^{58}$

One of the most well-known contemporary folk groups exploring Kalevala-type songs is Värttinä. Former lead singer Sari Kaasinen explained that the group began learning music in traditional Karelian contexts: "I am from a farm, we had cattle, cows-and I have lived, so to speak with them; it has been that sort of country life where all these traditional things have been a very strong part of life." ${ }^{\text {, }}$ Another former member, the instrumentalist Kari Reiman described the group's runo (kalevalaic song) repertoire as consisting of epic stories about gods and heroes, lyrical songs about human feelings, and magical spells. Runo originally signified a singer who could also be a shamanic figure, thus pointing to the cosmological dimensions of kalevalaic performance practices. Värttinä’s texts explore folk themes, including forest

55 Urpo Vento, “'The role of the Kalevala,” 89.

56 Kari Kallioniemi and Kimi Kärki, “The Kalevala, Popular Music, and National Culture,” Journal of Finnish Studies 13, no. 2 (2009): 62.

57 See http:/ / m.youtube.com/watch?v=snhbqmUN154\&desktop_uri=\%2Fwatch\%3Fv\%3DsnhbqmUN154 (accessed 1 November, 2019).

58 See http://www.youtube.com/watch?v=NXDKO9v8hSc (accessed 1 November, 2019). The musical genres within northern forest cultures are diverse. Another category of music, which is labelled explicitly as "forest" lies in archive collections. The Chairperson of the Finnish Forest History Society, Markku Rauhalahti (2005) reported on a collaborative project between the Finnish Forest History Society and Lusto, the Finnish Forest Museum, to collect forest-related songs, including archive sources.

59 Sari Kaasinen, personal interview 5 August, 1992, my translation; for more details, see Ramnarine: Ilmatar's Inspirations, 90. 
symbolism in traditional songs, notably in the title track to the album $\mathrm{O} i \mathrm{Da} i^{60}$ in which allegiance is expressed by a bride to her "own land, fir-trees and pine-trees." 61 Värttinä’s repertoire encompasses related Finno-Ugric songs by Setu, Mari, and Ingrian people, examples of which can be heard on albums such as $\mathrm{Oi} \mathrm{Dal^{62 }}$ and Seleniko. ${ }^{63}$ The group has incorporated joik (a traditional Sámi vocal genre) in songs like 'laulutyttö, ${ }^{, 64}$ 'outona omilla mailla, ${ }^{, 55}$ and 'Manattu. ${ }^{.66}$

A characteristic of runo performance is the interplay between the stress in words and musical meters. On the DVD Värttinä, Archive, Live (2006), two group members-the singer Mari Kaasinen and the violinist Kari Reiman—discuss the importance of singing in Finnish to preserve its linguistic rhythmic characteristics. As Reiman notes,

most of the traditional runos are in $5 / 4$ or $4 / 4$, but in many songs, when the singer is fitting words to a melody, the rhythms become very complicated and uneven. The first line might have 11 beats, but the next line 9, 10 or 13. We like those uneven rhythms and ever since Oi Dai's 'Viikon vaivane' (in 28/8) there's always been something in that style on our albums. ${ }^{67}$

Linguistic considerations likewise shape Karelian lament, which is included in Värttinä's repertoire, and which is also a genre going through a recent revival process. Part of the linguistic complexity of Karelian lament lies in its ritual aspects; in its conveying of the conceptual traces of the sacred forest as "a sociomorphic world structured as a self-portrait of the human community." ${ }^{\text {" }}$ Laments performed in wedding contexts traditionally depicted in-laws as bears of the forest, highlighting them as "foreign." " In contemporary lament, the use of ritual language continues a "dialogical mode of communication" in which personification of the forest links human and animal agency, enabling "the concept of a common language and verbal communication with the forest."

The world beyond the living is evoked in funeral laments. The ethnomusicologist Elizabeth Tolbert $^{71}$ notes the vestiges of nature-based shamanic cosmologies in lament performance. The lamenter

\footnotetext{
${ }^{60}$ Värttinä, Oi Dai (Oy Sonet Suomi Ab, SpiritCD4, 1991, CD).

${ }^{61}$ Ramnarine, Ilmatar's Inspirations, chapter 5.

62 Värttinä, Oi Dai, CD.

63 Värttinä, Seleniko (Oy Sonet Suomi Ab, Spirit 517.467-2, 1992, CD).

${ }^{64}$ On Värttinä, Vibma (Wicklow Records 0902663262 2, BMG Classics, 1998, CD).

${ }^{65}$ On Värttinä, Aitara (Mipu Music, MipuCD302, 1994, CD).

${ }_{66}$ With the joiker Wimme Saari on Värttinä, Utu (Rockadillo Records, ZENCD 2141, 2012, CD).

${ }^{67}$ Reiman, interview transcript on the DVD, Värttinä, Archive, Live (Sony BMG Music Entertainment, Hoedown Arts Oy and Provisual Oy, 82876855979, 2006, DVD).

${ }_{68}$ Tarkka, "Sense of the Forest," 96.

${ }^{69}$ Tarkka, "Sense of the Forest," 129.

70 Tarkka, "Sense of the Forest," 102.

${ }^{71}$ Elizabeth Tolbert, "Women cry with words: symbolization of affect in the Karelian lament," Yearbook for Traditional Music 22 (1990): 80-105.
} 
acts as a "bridge between worlds," employing a complex interplay of "speech, song and weeping.,"72 The musical structure is flexible and the pitches, mode, vocal range, and phrase structure are not fixed. The textual meaning is unclear. The lack of narrative clarity is achieved through metaphor, alliteration, and vocables. The sigh determines a descending melodic shape and the melody, as well as the rhythmic contour, is determined by linguistic considerations such as the number of syllables in the text. Lament is characterized by kinesthetic behaviors such as covering one's face, as well as by stylized sobs, a creaking voice, micro-tonal and micro-rhythmic variations, audible intakes of breath, and sighing, all of which display the singer's intense emotional involvement in the lament performance. ${ }^{73}$

One organization dedicated to reviving the Karelian lament tradition since 2001 is Äänellä Itkeminen ("Crying with the Voice"). ${ }^{74}$ Its web pages explain the emotional aspects of laments and crying as a process of self-care in the midst of nature. ${ }^{75}$ The organization noted that the tradition was endangered by the 1990s as the older generation of Karelian refugees to Finland was dying out, and that lament performance had become staged rather than occurring in real life ritual events. This organization's lament practices have been analyzed in terms of psychotherapeutic and New Age approaches. ${ }^{76}$ By 2008 , it had held forty courses in different places with nearly 600 participants. Today, it includes new performance events for reaching the age of confirmation, retirement, or natural disasters. For a sound example on the organization's web pages, Pirkko Fihlman (chairperson) performed a lament for the statue of Larin Paraske, the singer to whom Sibelius went to listen to Kalevala song and lament. ${ }^{77}$

Nineteenth-century Karelianism was a "cultural phase" characterized by "orientation towards mythicism," as the musicologist Eero Tarasti ${ }^{78}$ observed, and its legacy was a huge store of archive material, which has been used in the contemporary search for cultural heritage. The archive connects nineteenth- and twenty-first century laments in a new turn toward the mythical. Karelianism takes different forms. While Nuori Suomi (Young Finland) was a nineteenth-century pro-Finnish group that turned attention to Karelia within Finnish nationalism (in which context Sibelius's works can be understood), a contemporary regional movement does not define Karelia solely in terms of Finnish

\footnotetext{
72 Tolbert, "Women cry with words," 81.

73 See Tolbert, "Women cry with words."

${ }^{74}$ One of its teachers is the singer Karoliina Kantelinen, a current member of Värttinä, whose membership has changed several times since it was formed in 1983. See http:/ /www.karoliinakantelinen.fi/ (accessed 26 July, 2019). 75 See Äänellä Itkeminen's web pages at http://www.itkuvirsi.net/itkeminen.html (This web page is no longer available since it was initially accessed in 2013; it had been replaced by a Facebook page by 1 August, 2019).

${ }^{76}$ James Wilce, "Sacred Psychotherapy in the 'Age of Authenticity': Healing and Cultural Revivalism in Contemporary Finland," Religions 2 (2011): 566-589.

77 See http:/ /www.itkuvirsi.net/itkunäytteita.html. (This webpage is no longer available online in the format first accessed in 2013, but related pages emphasize that lament is an intangible cultural heritage within the frames of UNESCO's intangible heritage discourses, see https://wiki.aineetonkulttuuriperinto.fi/ (accessed 26 July, 2019).

${ }^{78}$ Eero Tarasti, Myth and Music: A Semiotic Approach to the Aesthetics of Myth in Music especially that of Wagner, Sibelius and Stravinsky (Berlin: Mouton de Gruyter, 1979), 12.
} 
nationalism. Neither is Karelianism defined in line with the competing interests of Russian imperialism or Soviet (post-) socialism: the political shifts that have been part of more recent Karelian experience. This point is illustrated by looking at twenty-first century Karelianism through the example of Karelian folk-rock in Russian Karelia.

Nineteenth-century representations of Karelia as a region of cultural riches have given way to a twenty-first century regional emphasis on the wood industry. ${ }^{79}$ Regional culture is emphasized, nevertheless, in the music of the Karelian folk rock singer Santtu Karhu and the members of his band Talvisovat. One of their recording labels is named Nuori Karjala ("Young Karelia")—an obvious play on the politics of "Nuori Suomi" ("Young Finland"). Karhu and the members of his band Talvisovat were major activists promoting Karelian language transmission and released recordings in 1990 and 1991. In the early 1990s, Karhu expressed his wish to continue using the endangered language Livvi (spoken in Aunus Karelia, and regarded as a Karelian dialect, as well as a distinct language). His formal education had been in Russian and he only spoke Livvi at home with one of his grandmothers. His mother spoke Russian, not Livvi. Karhu thought about the preservation of Karelian culture and language in comparative terms by reflecting on the cultures and languages of other related peoples, especially those who had been drawn into the Soviet Union, such as Estonians. Livvi is the language of some Kalevala meter songs, and Karhu stressed its importance and beauty, as well as his hopes that it would be in general use again in the future. ${ }^{80}$ Karelian language transmission continued into the twenty-first century through the medium of popular music because Perestroika offered new cross border travel possibilities and gave musicians new musical models, according to the musicologist Pekka Suutari. Thus, Karelian rock musicians had turned, initially, to Karelian languages as a form of protest within the Soviet Union, following the example set by Estonian rock musicians. This musical protest was important for language maintenance. As Suutari claims, Karhu's audience is "still relatively small in Russian Karelia, but his influence is huge for those young people who would like to see the Karelian language reappear as a vital medium in the community." 81 In a press interview given in 2003, Karhu expressed his pride in singing in a suppressed, forgotten, and degraded language. ${ }^{82}$ On the Internet, examples uploaded to YouTube for an international web audience include Karhu's reworking of early twentieth-century ethnographic materials, most

\footnotetext{
${ }^{79}$ Maunu Häyrynen: “A periphery lost: the representation of Karelia in Finnish national landscape imagery," Fennia 182, no. 1 (2004), 23-32.

${ }^{80}$ Santtu Karhu, personal interview 14.12.1991, for further details see Ramnarine, Ilmatar's Inspirations, 176-181.

${ }^{81}$ Pekka Suutari, "Perestroika! Transnational Positions of Russian Karelian Popular Music," in The Oxford Handbook of Popular Music in the Nordic Countries, eds. Fabian Holt and Antti-Ville Kärjä (New York, Oxford: Oxford University Press, 2017), 242.

82 Peipa Mäki, "Santtu Karhu: Ensimmäinen karjalankielinen rocklevy” ("Santtu Karhu: The first Karelian language rock record"), in: Kaltio: Pohjoinen Kulttuurilehti ("Kaltio: Northern Culture Newspaper"), 2003, http:/ /www.kaltio.fi/vanhat/index3c59.html?21 (accessed 1 November, 2019), no pagination.
} 
brilliantly in Karjalazes diskotiekas, which is a rescoring of a film extract of a wedding in Suojärvi. ${ }^{83}$ Karhu replaces the soundtrack by the composer and ethnographer Armas Launis (a researcher of Karelian and Sámi music, and also a student of Sibelius) with extracts from his own recording. ${ }^{84}$ The traditional Karelian dance choreographies captured on the early ethnographic documentary film are re-represented as examples of Karelian hip hop, breakdance, and Michael Jackson choreographic moves, and they are labeled in terms of popular dance cultures in the YouTube upload. By re-contextualizing the ritual significance of the wedding and of traditional dance choreographies, Karhu's creative approach to historical ethnographic data highlights the contemporary relevance of earlier scholarship, as well as of traditional performance practices and pre-industrial ways of living that might still yield riches_cultural, social, and ecological. ${ }^{85}$

\section{Conclusion}

This article has suggested ways of understanding music in the context of northern forest cultures by looking at examples that span over a century, ranging from Sibelius's nature-based aesthetic, which was rooted, literally, in the forest ecologies within which he lived and worked, to the contemporary folk and popular music of Värttinä and Santtu Karhu and his band Talvisovat.

It has offered a further perspective on disciplinary concerns about resilience, which have been expressed in different ways, including cultural survival, preservation, cultural grey-out, revival, the transmission of tradition, or musical change, all of which have given way today to a pronounced discourse on sustainability. Musical practices are assessed in terms of their continuing vitality and viability in the present day, ${ }^{86}$ and they are incorporated into discourses on intangible cultural heritage. In some recent cases, ethnographers believed they were documenting disappearing musical traditions. This has been the case in Finno-Ugric research contexts, especially around the turn of the twentieth century. Yet, it is almost impossible for an ethnographer, who is situated in a particular temporal frame, to predict cultural futures, even while assessing contemporary cultural vitality. ${ }^{87}$ The approach to cultural survival in this article, therefore, has departed from assessments of vitality to highlighting traditional conceptual connections

${ }^{83}$ Häidenvietto Karjalan runomailla ("A Wedding in the Karelian Songlands"), DVD, Ethnographic film originally made by A. O. Väisänen, U. T. Sirelius, and Armas Launis; released in 1921 by the Kalevala Society, Helsinki, Finland, Re-released in 2006 (Helsinki: Finnish Literature Society, Music by Armas Launis, 2006 [1921]).

${ }^{84}$ Santtu and Talvisovat Karhu, Allus oli muna (Hot Igloo, HI-009, 2009, CD).

${ }^{85}$ See https:/ /www.youtube.com/watch?v=789LTIw4aGo (accessed 7 November, 2019).

86 Jeff Todd Titon, ed., World of Music Special Issue: Music and Sustainability 51, no. 1 (2009).

Catherine Grant, "Key Factors in the Sustainability of Languages and Music: A Comparative Study," Musicology Australia 33, no.1 (2011), 95-113.

${ }^{87}$ E.g. the case of Karl Tirén who recorded Sámi music in Sweden in the early nineteenth century and believed he was witnessing a dying tradition, see Richard Jones-Bamman, "Following in the Footsteps of a Giant," British Journal of Ethnomusicology 12, no. 1 (2003): 35-54. 
between music and ecology, and how these have been framed by specific political, scholarly, and artistic concerns with sustainability.

Nevertheless, referencing the musical in relation to the ecological (specifically conceptualizing cultural continuity in terms of sustainability and resilience) has a concrete basis when viewed from the perspectives of how ecologies shape cultural practices. In the northern regions of Europe, polar warming, for example, is beginning to affect musical thought, and a critique of the dangers to a fragile ecology is expressed via creative activism. Musical responses to changing sonic environments generate wider public attention to ecological crises. ${ }^{88}$ The discussion in this article has gone beyond determinist models of northern forests by emphasizing that forest cultures in Finno-Ugric contexts have had political dimensions in projects of nationalism, regionalism, and language maintenance. Sámi indigenous politics provide important and related perspectives on cultural survival and ecological thought, too, as discussed elsewhere. ${ }^{89}$ The examples discussed in this article have led to thinking holistically about common ecological, linguistic, and cultural Finno-Ugric heritages despite different kinds of identity politics. This is a fundamental point. When it comes to thinking about fragile ecologies, a global view is needed, not a regional or a national one.

The larger questions therefore concern the future of forests in the global context, and they extend to thinking about the survival of different kinds of forest cultures, through which human knowledge about forests is transmitted. In an optimistic vein, the Finno-Ugric examples in this article provide evidence of cultural resilience, which, together with climate stability, is a key concern in thinking about contemporary ecological sustainability. Traditional Finno-Ugric cultural thinking emphasizes kinship relationship between humans and forests. This perspective is reiterated in contemporary scientific approaches to forests. Nadkarni writes that

we have a clear affinity ... for trees. Although we are not of the same family, trees and humans are in a sense married into each other's families, with all the challenges, responsibilities, and benefits that come from being so linked. From the first glimmers of humanity's dawn, we have evolved with trees. ${ }^{90}$

This affinity is so strong that trees provide the metaphors for thinking about various kinds of human relationships and communication media: tree imagery is a conceptual tool in abstract modes of thinking about human language evolution and linguistic proximity. ${ }^{91}$

\footnotetext{
88 Ramnarine, “Acoustemology, Indigeneity and Joik in Valkeapää’s Symphonic Activism”; Ramnarine, "Sonic Images of the Sacred in Sámi Cinema."

${ }^{89}$ Discussed, for example, in Ramnarine, "Sonic Images of the Sacred in Sámi Cinema"; as well as in Ramnarine, "Musical Creativity and the Politics of Utterance."

${ }_{90}^{0}$ Nadkarni, Between Earth and Sky, 11.

${ }^{91}$ Nadkarni, Between Earth and Sky, 57.
} 
Cultural resilience is threatened by contemporary environmental challenges. The ecological turn in music scholarship is a critical response to the need to confront uncertainty. Although much ecological modeling is based on forecasting future scenarios, it is worth dwelling on the idea of the sacred forest, which persists in Finno-Ugric musical practices to the present day. Most importantly, the idea of the sacred forest rests on the life-giving properties of trees. It foregrounds the forest as essential to the survival of our, and other, species. 